\title{
Microbial Load and Innocuousness of the Extract of Plants Obtained from Banana Rachis Leachate Produced in Cuba
}

\author{
Lilián M Morales Romero ${ }^{1 *}$, Mabel Izquierdo², Yenay Díaz León ${ }^{2}$ and Lisbett Melo Acosta² \\ ${ }^{1}$ Research Institute of Tropical Roots and Tuber Crops (INIVIT), Santo Domingo, Villa Clara, Cuba \\ ${ }^{2}$ Microbiology Laboratory. Center for Genetic Engineering and Biotechnology (CIGB), Havana, Cuba
}

*Corresponding author: Lilián MMorales Romero, Researcher, Pest Management Department. Postal Address: Instituto de Investigaciones de Viandas Tropicales (INIVIT), Cuba

ARTICLE INFO

Received: 幽 July 25, 2020

Published: August 11, 2020

Citation: René Hage, Carolin Steinack, Macé M Schuurmans. Calcineurin Inhibitors in COVID-19: Lessons Learnt from Transplantation Medicine. Biomed J Sci \& Tech Res 29(3)-2020. BJSTR. MS.ID.004802.

\begin{abstract}
The objective of this research was to determine the microbiological composition and innocuousness of banana leachate, obtained at the Research Institute of Tropical Roots and Tuber Crops (INIVIT) in Santo Domingo, Villa Clara, Cuba. The determination of the microbial load and innocuousness of the leachate analyzed was carried out through established procedures at the Microbiology Laboratory of the Center for Genetic Engineering and Biotechnology (CIGB). The results obtained in the research are the scientific basis for encouraging the use of banana rachis leachate, as a high value-added product. The microbial load determined in this study $4.4 \times 106 \mathrm{CFU} / \mathrm{mL}$ from bacteria of the genus Bacillus sp. and its innocuousness as it is free of pathogenic microorganisms, such as Escherichia coli and Salmonella sp., were findings of great importance. The research helps to encourage the use of a crop residue, underused in the production process of plantains and bananas in Cuba.
\end{abstract}

Keywords: Leachates; Musaceae; Residues; Microbial Composition

\section{Short Communication}

In the production of plantains and bananas, as in most of agricultural production systems, large amounts of residues or waste are generated, such as reject fruits, pseudo-stems, leaf litter and rachis, mainly. In this regard, investigations carried out in Cuba, considering an average value into the percentage of rachis weight $(11 \%)$ and its representativeness at the annual level production of plantains and bananas in the country $(675,405.1 \mathrm{t})$, can mean values of 74,294.6 $t$ of cluster rachis. These data reaffirm that the production of plantains and bananas in Cuba, causes a considerable amount of organic waste, which are not properly used and they could be reused [1].The Food and Agriculture Organization of the United Nations (FAO) promotes experiences in Latin America and the Caribbean, focused at reducing food loss and waste, and the use of by-products or residues, which contribute to the improvement of environmental health conditions in the context of integrated and efficient productive systems [2]. Leachates from edible musaceae (plantains and bananas) are plant extracts, obtained by decomposition of harvest residues [3,4]. The rachis leachate (flower peduncle, also known as pinzote or stem, has a helical shape and it is the responsible for the support of clusters), as it is a product of the same plant, it has essential nutrients ( $\mathrm{N}, \mathrm{K}, \mathrm{Fe}, \mathrm{Mn}, \mathrm{Na}, \mathrm{Cu}$ ) that can be reused for the crop itself [5-7]. These plant extracts applied to banana seedlings under nursery conditions, have proven to be effective in the growth of them, with a significant increase in the variables (height, number of leaves, as well as the total length and fresh and dry weight of the roots) $[8,9]$. Besides the nutritional value of this extract of plants, its potential as a pest and pathogen controller has been studied. This is attributed to the large number of microorganisms present in them $[10,11]$. Special interest has aroused the use of leachates to reduce the infective process of the 
most destructive diseases that threaten the production of plantains and bananas worldwide: Mycosphaerella fijiensis Morelet (black Sigatoka) and Ralstonia solanacearum Smith (moko) [4,12-15].

Other existing studies support the rachis use for other purposes, such as: ingredient for the production of flours, paper, ferments, livestock fodder, and even as a seed germination mechanism [1618]. At the Research Institute of Tropical Roots and Tuber Crops (INIVIT), a constant production volume of $200 \mathrm{~L}$ of extract of plants was obtained by the rachis decomposition of Musa AAA, subgroup Cavendish, cultivar 'Gran enano', from $700 \mathrm{~kg}$ of rachis, for an efficiency of $30 \%$ by the end of 2019 and beginning of 2020 [1]. The authors propose the rachis leachate as a way to take advantage of an invaluable residue in the current economic situation of the Cuban agriculture.The INIVIT devotes efforts through its research-development programs and collaboration with scientific centers, to the study of rachis leachate production processes, its components, nutritional effect and disease managements. Nowadays, investigations aimed at the chemical characterization of rachis leachates of plantains and bananas, have received more attention than the studies dedicated to the detection of microorganisms or bioload present in them $[8,9,13]$. This research carried out in collaboration with the Center for Genetic Engineering and Biotechnology (CIGB) aims to determine the microbiological composition and innocuousness of banana leachate, obtained at the INIVIT, to understand the action mechanism as a biological controller, improve the production efficiency and encourage its use in organic and sustainable production systems.

\section{Materials and Methods}

The determination of the microbial load and innocuousness of the extract of plants, obtained from the banana rachis leachate (Musa AAA, subgroup Cavendish, cultivar 'Gran enano') was carried out at the Microbiology Laboratory, which belongs to the Center for Genetic Engineering and Biotechnology (CIGB) in Havana, Cuba, in March 2020.The banana rachis leachate analyzed in the research was obtained at the Research Institute of Tropical Roots and Tuber Crops (INIVIT). The sample for the study corresponds to a new leachate (phase less than one production year), taken from a plastic recipient that contained the leachate kept, under curing conditions, for more than 30 days. The rachis used to obtain the leachate were collected at the processing and packaging factory of the Agricultural Enterprise Quemado de Güines, located in Villa Clara province.The sample received at the Microbiology Laboratory of the CIGB was kept in refrigeration at a temperature of 2-80C until its processing in March 2020. The sample analysis was performed following the procedure 4.09.290.91. (Microbiological analyses of non-sterile products).

\section{Procedure Performed for Bioload Determination}

Ten $\mathrm{mL}$ of the sample were taken and added in $90 \mathrm{~mL}$ of Peptone Salt Solution. From this first dilution, serial dilutions were made up to 10-5. Later, $1 \mathrm{~mL}$ was filtered in duplicate of the dilutions 10-3, 10-4 and 10-5. The membranes were placed in plates, containing Triptone Soy Agar and incubated from 30-350C, for a period of 72 hours.

\section{Procedure Performed for the Determination of Escherichia Coli}

Ten $\mathrm{mL}$ of the first dilution described above were taken and transferred to $100 \mathrm{~mL}$ of Triptone Soy Broth and incubated for 24 hours, at temperatures from 30-350C. After this period, $1 \mathrm{~mL}$ was inoculated into $100 \mathrm{~mL}$ of Mac Conkey Broth and incubated at 42 0C for 24 hours. Then, it was moved to Mac Conkey Agar plates and incubated from 30-350C for 48 hours.

\section{Procedure Performed for the Determination of Salmonella sp.}

It was taken $0.1 \mathrm{~mL}$ of the previous enrichment in Triptone Soy Broth and transferred to a tube containing $10 \mathrm{~mL}$ of Rappaport Vassiliadis Broth. It was incubated from 30-350C for 24 hours and moved to Xylose Lysine Deoxycholate (XLD) Agar plates, incubating from 30-350C for 24 hours.

\section{Results and Discussion}

After the incubation period of each one of the determinations, it was obtained as a relative result to the Bioload, that in the dilution 10-5 grew 41 and 46 Colony Forming Units (CFU), respectively on each replica plate, so the concentration in the analyzed leachate was $4.4 \times 10^{6} \mathrm{CFU} / \mathrm{mL}$. The contaminants that predominated were mainly sporulated gram-positive bacilli, identified as Bacillus sp.Among the characteristics of the genus Bacillus, its aerobic or sometimes facultative anaerobic growth, Gram-positive, bacilar morphology, flagelar mobility and variable size $(0.5$ to $10 \mu \mathrm{m})$ stand out. Its optimal growth occurs at neutral $\mathrm{pH}$, presenting a wide range of growth temperatures, although most species are mesophilic (temperature between 30 and $45^{\circ} \mathrm{C}$ ).Investigations carried out to determine the microbiological composition and innocuousness of banana leachates, conducted by the National Institute of Agricultural Research (INIA) and the National Center for Agricultural Research (INIA-CENIAP) in Venezuela, indicate the bacteria identification of the genus Bacillus, as the microorganisms involved in the decomposition of fresh matter [19]. The chemical and microbiological characterization of an organic fertilizer, based on the use of residues from the harvest of bananas, showed that the greatest presence of microorganisms found were bacteria, although the genus was not identified [20]. The finding in this research is very important, due to the role of bacteria of the genus Bacillus, associated with the promotion of plant growth and control of pathogens [21-25]. A relevant aspect that distinguishes the bacteria of this genus is the ability to produce endospores, as a resistance mechanism to various types of stress [24,26,27].

The role of bacteria of the genus Bacillus as producers of growth phytoregulators, like cytokinins and gibberellins [28] could help to 
interpret the effect of these extracts on the growth of plantain and banana vitroplants, reported by several authors. This reaffirms the importance of studying the composition of banana rachis leachates that determines its effectiveness in the control of diseases and growth promotion to improve its production.On the other hand, the microbial load determined in this study is above 1x106 CFU/ $\mathrm{ml}$, considered as the necessary application dose, for these bacteria to exert their effect [29]. It is inferred that in the leachate obtained at the INIVIT, there are sufficient amounts of Bacillus to produce a possible response in the plants. Currently, our working group is conducting other leachate evaluations, obtained with a view to better understand its use and potential, as a biological controller for its integration into disease management programs in Musaceae. Biological control strategies have got importance in recent years and at the present time, they are main links in pest management programs in Cuba. They are an alternative to the use of chemical synthesis products, in the management of harmful organisms or pest causal agents. Unfortunately, the increase in food demand and the resistance of pests have forced farmers to increase agrochemical and pesticide inputs, as the main control method. The indiscriminate use of these ones may cause damage to health and the environment [30,31].

The results related to the determination of Escherichia coli and Salmonella sp. are reflected in Table 1.In relation to the leachate innocuousness, the results show the absence of Salmonella sp. and E. coli (Table 1), which is of most importance, since the international health organizations demand, as an indispensable control requirement for the use of these products, that these microorganisms must be at very low populations or absent to consider the product innocuous. The results obtained in terms of innocuousness and bacteria presence of the genus Bacillus, could encourage the use of rachis leachate in agro-ecological production systems and minimize the use of chemical substances that contaminate the environment, in addition to lower production costs, advantages that promote the use of this practice in the Cuban agro-ecosystems.

Table 1: Determinationof Escherichia coli and Salmonella sp.in ananalyzedsample.

\begin{tabular}{|c|c|}
\hline Determinationof Escherichia coli & Determinationof Salmonella sp. \\
\hline Absence & Absence \\
\hline
\end{tabular}

\section{Conclusion}

The results obtained in this research are the scientific basis to support the use of rachis leachates of bananas, obtained at the INIVIT, as a high value-added product. The microbial load determined in this study $4.4 \times 106 \mathrm{CFU} / \mathrm{mL}$ from bacteria of the genus Bacillus sp. and its innocuousness as it is free of pathogenic microorganisms, which can harm plants or human beings are findings of great value that contribute to encourage the use of a crop residue, underused in the production process of plantains and bananas. It is recommended to continue studies to isolate, identify, purify and lyophilize these bacteria and evaluate the possibility of their use as biological controllers.

\section{Acknowledgement}

The authors of this work express our gratitude to producers and workers of the processing and packaging factory of the Agricultural Enterprise Quemado de Güines, located in Villa Clara province, for providing us with a permanent rachis supply that has enabled the development of the Leachate Production Center. We also thank the Direction of the Center for Genetic Engineering and Biotechnology (CIGB) of Havana, for the full availability of its laboratories and scientific staff, which allowed the performance of this research.

\section{References}

1. Morales L, Maza N (2020) Obtención de lixiviado de raquis de plátanoen el INIVIT. Rev. Agricultura Tropical 6(1): 60-60.

2. FAO (2015) Pérdidas y desperdicios de alimentosen América Latina y el Caribe. Boletín 2, abril.

3. Larco ES (2004) Desarrollo y evaluación de lixiviados de compost y lombricompost para el manejo de Sigatoka negra (MycosphaerellafijiensisMorelet), enplátano. Tesis M.Sc. Escuela de Posgrado. Programa de Educación para el Desarrollo y la Conservación. Centro Agronómico Tropical de Investigación y Enseñanza (CATIE). Turrialba, Costa Rica. P. 77

4. Arenas A, López D, Álvarez E, Llano G, Loke J (2005) Efecto de prácticasecológicassobre la población de Ralstonia solanacearum Smith, causante de Moko de plátano. FitopatologíaColombiana 28(2): 76-80.

5. Cabral D (2006) Microbiological quality of organic vegetables produced in soil treated with different types of manure and mineral fertilizer. Brazilian Journal of Microbiology. 37(4): 538-544.

6. Smesrud J, Duvendack G, Obereiner J, Jordahl J, Madison M (2012) Practical salinity management for leachate irrigation to poplar trees. International Journal of Phytoremediation 14(S1): 26-46.

7. Chávez EV, Valencia OA, Córdova NC, Flores E, Rodríguez J, et al. (2017) Lixiviados de Raquis de Plátano: Obtención y UsosPotenciales. Cuadernos de Biodiversidad 53(2017): 1-8.

8. Garcés HHM (2010) Comparación de la calidad y efectos de lixiviadosobtenidos a partir de raquis de banano (Musa acuminata) y plátano (Musa balbisiana) mediantetransformaciónaeróbica y anaeróbicaencondiciones de invernadero. Trabajo de Grado para la obtención del título de IngenieroAgropecuario, Escuela Politécnica del Litoral, Facultad de IngenieríaenMecánica y Ciencias de la Producción. Guayaquil, Ecuador p. 133.

9. Blanco GB, Linares YR,Guédez (2011) Efecto de lixiviadosprovenientes de restos de cosecha de plátanosobre el crecimiento de vitroplantas de 'PlátanoHartón'. In: Memorias de III Encuentro Nacional de la Red de BiotecnologíaAgroalimentaria de Venezuela. Maracay, del 05 al 09 de diciembre de.

10. Staley BF, De los Reyes FL, Barlaz MA (2012) Comparison of bacteria and archaea communities in municipal solid waste, individual refuse components, and leachate. FEMS Microbiol Ecol 79(2): 465-473.

11. Xu D, Raza W, Yu G, Zhao Q Shen Q et al. (2012) Phytotoxicity analysis of extracts from compost and their ability to inhibit soilborne pathogenic fungi and reduce root knot nematodes. World Journal of Microbiology and Biotechnology 28(3): 1193-1201. 
12. Mainer Y (2009) Control de la Sigatoka negra (Mycosphaerellafijiensis) del plátano con productos naturales (Lixiviado y Antagonistas). Tesis M.Sc. Biología y Tecnología de Vegetales. Universitéd’Angers. Institut National d'Horticulture et du Paysage. Francia. P. 70.

13. Ortiz MF (2009) Evaluacin de la actividad de los lixiviados de raquis de Banano (Musa $\mathrm{AAA}$ ), Plátano (Musa AAB) y BananoOrito (Musa AA) sobre el agente causal de la Sigatoka negra (MycosphaerellafijiensisMorelet) encondiciones in vitro. Tesis de grado. Facultad de IngenieríaAgropecuaria. Escuela Superior Politécnica del Litoral. Guayaquil, Ecuador.

14. Mogollón O, Maria A, Zapatla C (2010) Evaluación in vitro de lixiviados del raquis de plátanosobreParacercosporafijiensis (Morelet) Deighton. Agron 18(2): 17-23.

15. Álvarez E, Pantoja A, Gañán L, Ceballos G (2013) Estado del arte y opciones de manejo del Moko y la Sigatoka negraen América Latina y el Caribe. Centro Internacional de Agricultura Tropical (CIAT), Cali, CO. (CIAT № 387) pp. 40.

16. Russo R (1995) Efecto de un bioestimulantehúmicoextraído del raquis de banano (pinzote) sobre el crecimiento de plántulas de banano (Musa AAA subgrupo "Cavendish" clon Gran Enano). AgronomíaMesoamericana 6: 130-133.

17. FAO (2012) Organización de las NacionesUnidas para la Alimentación y la Agricultura. Statistical Yearbook 2012 World Food and Agriculture. Food and Agriculture Organization of the United Nations. Rome, Italy, pp. 369.

18. Oracz K, Voegele A, Tarkowská D, Jacquemoud D, Turecková V, et al. (2012) Myrigalone A inhibits Lepidium sativum seed germination by interference with gibberellin metabolism and apoplastic superoxide production required for embryo extension growth and endosperm ruptura. Plant \& cell Physiolog 53: 81-95.

19. Blanco G, Linares B, Hernández J, Maselli A, Rincón A, et al. (2013) Composiciónmicrobiológica e inocuidad de lixiviados de pseudotallos y láminasfoliares de plátano 'Hartón' en el estado Yaracuy. Agronomía Trop. 63(3-4): 111-120.

20. Ramos DA, Terry E, Soto F, Cabrera JA (2014) Bocashi: Abonoorgánicoelaborado a partir de residuos de la producción de plátanosen Bocas del Toro, Panamá. CultivosTropicales 35(2).

21. Idriss EE, Makarewicz O, Farouk A, Rosner K, Greiner R, et al. (2002) Extracellular phytase activity of Bacillus amyloliquefaciens FZB45 contributes to its plant-growth-promoting effect. Microbiology 148: 2097-2109.

ISSN: 2574-1241

DOI: $10.26717 / B J S T R .2020 .29 .004803$

Lilián M Morales Romero. Biomed J Sci \& Tech Res

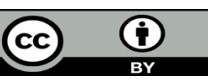

This work is licensed under Creative Commons Attribution 4.0 License

Submission Link: https://biomedres.us/submit-manuscript.php
22. Robles C, BareaJM (2004) Respuesta de la plantay delsueloala inoculación con Glomus intraradices y rizobacteriasenmaízencultivointensivo. Terra Latinoamericana 22(1): 59-69.

23. Corrales LC, Sánchez LC, Cuervo J, Bautista D, González L, et al. (2011) Evaluación del efectobiocontrolador de Bacillus spp., frente a Fusarium spp., bajo condiciones de invernaderoen Rosmarinus officinalis L. NOVA PublicaciónCientíficaenCienciasBiomédicas. 8(13):63-75.

24. Tejera-Hernández B, Rojas-Badía MM, Heydrich-Pérez M (2011) Potencialidades del género Bacillus en la promoción del crecimiento vegetal $\mathrm{y}$ el control de hongosfitopatógenos. Revista CENIC CienciasBiológicas 42: 131-138.

25. Gómez-Luna BE, Hernández-Morales A, Herrera CH, Méndez BE, ArroyoFigueroa G, et al. (2012) Aislamiento de bacteriaspromotoras del crecimiento de la rizósfera de plantas de guayaba (Psidium guajava). Ra Ximhai 8(3): 97-102.

26. Velez PV, Zúñiga D (2010) Caracterizaciónfisiológica de cepas de Bacillus spp. aisladas de la rizósfera de papa (Solanum tuberosum). EcologíaAplicada 9(1): 31-39.

27. Layton C, Maldonado E, Monroy L, Corrales LC, Sánchez LC (2011) Bacillus spp.; perspectiva de suefectobiocontroladormediante antibiosis encultivosafectados por fitopatógenos. Revista NOVA PublicaciónCientíficaenCienciasBiomédicas 9: 177-187.

28. Glick BR (2012) Plant Growth promoting bacteria: Mechanisms and applications. Review Article. artículo ID963401 p. 15.

29. Hernández-Castillo FD, Lira-Saldivar RH, Cruz-Chávez L, GallegosMorales G, Galindo-Cepeda ME, et al. (2008) Potencialantifúngico de cepas de Bacillus spp. y extracto de Larreatridentata contra Rhizoctonia solanien el cultivo de la papa (Solanum tuberosum L.). RevistaInternacional de Botánica Experimental ФYTON 77: 241-252.

30. Pérez-García A, Romero D, de Vicente A (2011) Plant protection and growth stimulation by microorganisms: Biotechnological applications of Bacilli in agriculture. Current Opinion in Biotechnology 22: 187-193.

31. Guzmán Cabrera A, Noa Carrazana JC, Escalante-Rebolledo MA, Susan Tepetlán PV (2017) Evaluación del suelo y residualidad de plaguicidasensuelosdedicados al cultivo de bananodominicoenTlapacoyan, Veracruz. I CongresoInternacional de Ingeniería Ambiental, Colegio de IngenierosAmbientales de México A. C. 21-23 de febrero de. Villahermosa, Tabasco, México.

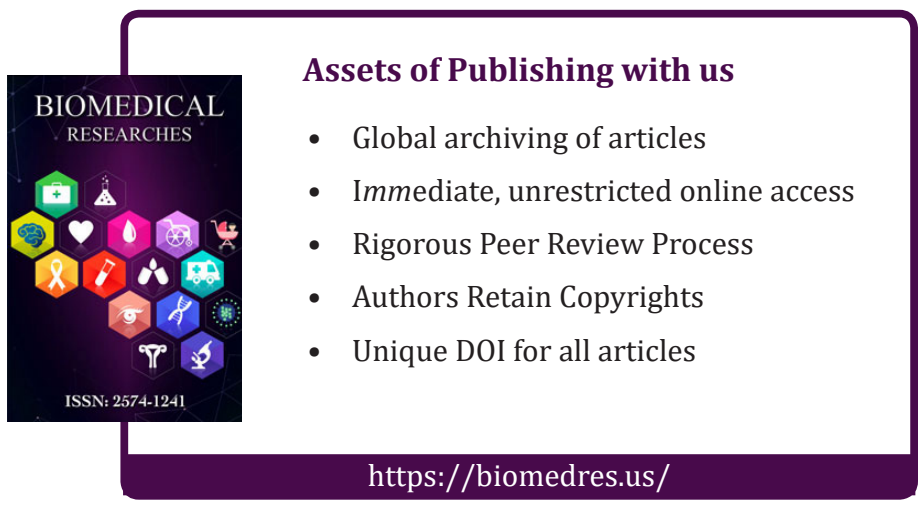

Copyright@ Lilián M Morales Romero | Biomed J Sci \& Tech Res | BJSTR. MS.ID.004803. 